\title{
Modulatory Role of Selenium Nanoparticles and Grape Seed Extract Mixture on Oxidative Stress Biomarkers in Diabetic Irradiated Rats
}

\author{
Rasha Mohamed Ahmed Abdelaleem¹, Hanan Fahmy Abdel Hameed ${ }^{1 *}$, Mervat El-Sayed Askar², \\ Seham Hassan Mohamed Hassan ${ }^{1}$ and Ahmed Ibrahim El-Batal ${ }^{1}$
}

${ }^{1}$ Drug Radiation Research Department, National center for radiation research and Technology, Atomic Energy Authority, Egypt.

${ }^{2}$ Biochemistry Department, Faculty of Pharmacy Zagazig University, Egypt.

\begin{abstract}
Introduction: Diabetes is a metabolic disorder of several etiologies, many oral anti-hyperglycemic agents such as sulfonylurea, biguanides are obtainable, but these agents have side effects, thus there is need of a new natural anti-hyperglycemic agent. Methods: The present study was performed to evaluate the protective role of selenium nanoparticles-grape seed extract (SeNPs-GSE) mixture in ameliorating the changes in the oxidative stress biomarkers induced by gamma radiation in diabetic rats. Experimental model of diabetic irradiated rats was induced by single intrapertoneal injection of streptozotocin (STZ $45 \mathrm{mg} / \mathrm{kg}$ ) followed by $\mathrm{y}$-radiation exposure (4 Gy). Forty eight rats were randomly classified into 6 experimental groups: normal, diabetic, irradiated, diabetic irradiated, diabetic treated with either SeNPs-GSE mixtureor glimepiride(1 mg) for (14) days followed by $\gamma$-radiation. Results: Results of the present study indicated that rats exposed to $y$-radiation and, or STZ significantly increase serum glucose\& liver MDA levels. This increase was accompanied by a decrease in the levels of serum insulin, total antioxidant (TAC), liver enzyme activities of catalase (CAT), glutathione peroxidase (GPx), superoxide dismutase (SOD), as well as liver tissue contents of vitamin C (Vit.C) and vitamin E (Vit.E). Diabetic rats treated with (SeNPs-GSE) mixture or glimepiride before $y$-radiation exert a significant improvement in all tested biochemical parameters. Conclusion: The present study showed that a mixture of (SeNPs -GSE) possesses antioxidant and anti-diabetic activities by decreasing oxidative stress biomarkers as well as blood glucose level tested in this study. The tested combination (SeNPs-GSE) mixture is more or less equally active as that of the standard tested anti-diabetic drug glimepiride
\end{abstract}

Key words:Diabetes mellitus, Selenium nanoparticles, Grape seed extract, Oxidative stress, Vitamin C, E.

\section{INTRODUCTION}

Radiotherapy is frequently used as a part of cancer treatment to attain tumor control. It might produce harmful effects to adjacent healthy tissues. ${ }^{1}$ Ionizing radiations induce oxidative stress, mainly through the generation of reactive oxygen species(ROS) resulting in imbalance of the pro-oxidant and antioxidant in the cells and attack different cellular macromolecules leading to cell death. ${ }^{2}$ Diabetes mellitus (DM) is a pathologic conditions resulting in severe metabolic imbalances in many tissues. It generates ROS through various pathways, such as damage of the redox equilibrium or overproduction of mitochondrial superox- ides, which leads to oxidative stress in variety of tissues. ${ }^{3}$ Glimepiride is a sulfonylurea antidiabetic drug indicated to treat type 2 diabetes mellitus; its mode of action is to increase insulin production by the pancreas. ${ }^{4}$ Several radioprotectors have been tested to find out if their administration before or during irradiation diminishes radiation induced damage to the body. ${ }^{5}$ Although synthetic radioprotectors such as aminothiols have yielded the highest protective effects, they are typically more toxic than naturally protectors. ${ }^{6,7}$ Herbal medicines with antioxidant resources have attracted great attention as possible radiation protec-
Submission Date : 04-01-2015 Revision Date : :22-06-2015 Accepted Date : :19-07-2015

DOI: 10.5530/ijper.50.1.21 Correspondence Address Dr. Hanan Fahmyabdelhameed

Drug radiation research Department, Biochemistry Lab, Nasr City Cairo, Egypt. Email:fahmy.hanan@yahoo. com

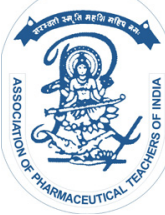

www.ijper.org 


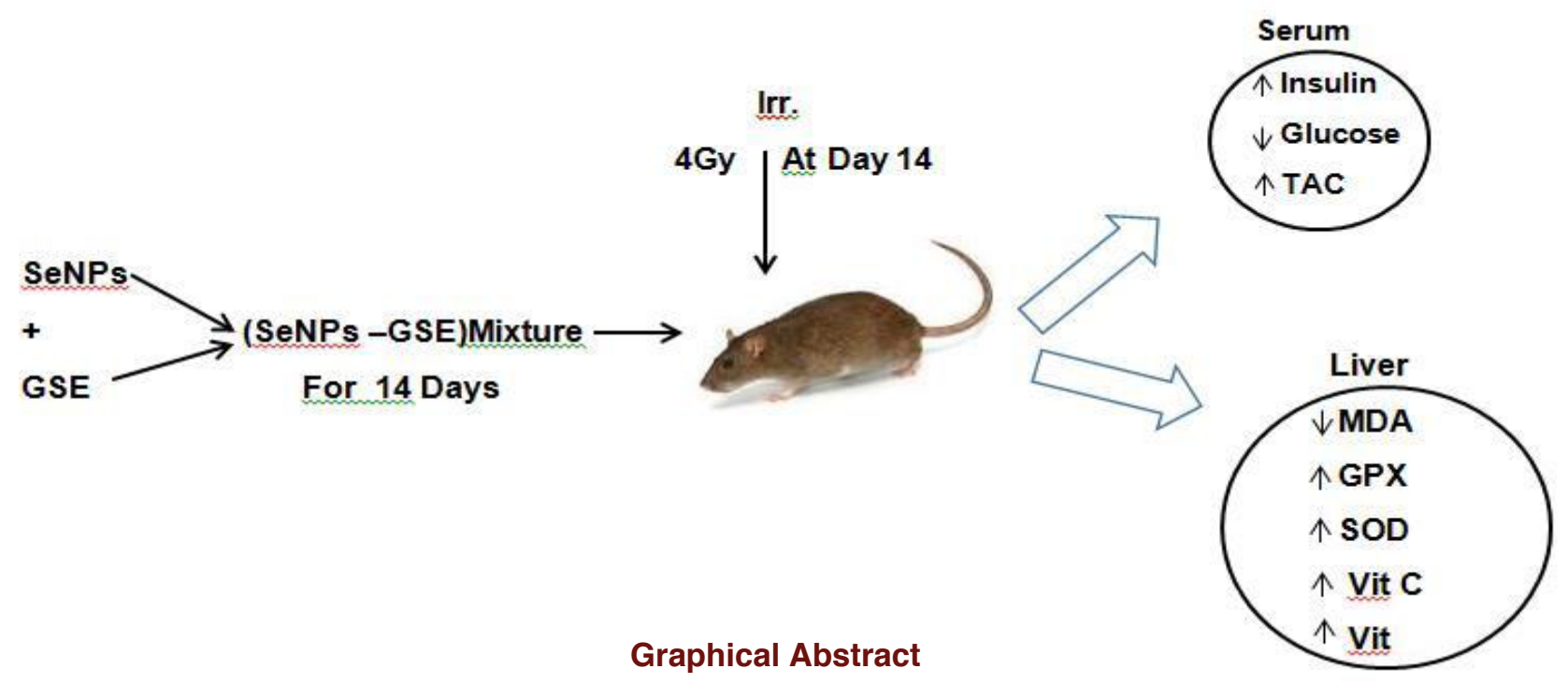

tor. ${ }^{8}$ Among the natural products, grape seed extract (GSE) compounds are attracting the interest because of their beneficial effects in human health. GSEcontains vit E,flavonoids, linoleic acid, proanthocyanidines. ${ }^{9}$ Proanthocyanidins were shown to have a role in lowering cholesterol levels, ${ }^{10}$ anti-inflammatory, cardioprotective, anticarcinogenic, and antioxidant activities. ${ }^{11}$

Nanotechnology is the creation of of matter on the nanometer length scale $(1-100 \mathrm{~nm})$. Materials at the nanometer dimension exhibit novel properties different to those of both isolated atoms and bulk material such as increase bioavailability of drugs, development of new medicines which are more safe, as well as nanoparticles can be administered via different routes like inhalation, through skin, orally, intravenous injection and intraperitoneal injection. ${ }^{12,13}$ Development of newer drug delivery systems based on nanotechnology methods is being tried for conditions like cancer, diabetes, fungal infections, and viral infections and in gene therapy. The main advantages of this modality of treatment are targeting of the drug and enhanced safety profile. ${ }^{14}$ Previous study reported an association between (DM) and alterations in the metabolism of several trace minerals such as magnesium, selenium, vanadium. ${ }^{15}$

Selenium (Se) is a nutritional trace element with notable antioxidant characteristics. It can inhibit many inflammatory cell mechanisms through antioxidant seleno enzymes. ${ }^{16}$ Selenium improved glucose homeostasis in diabetic rats. ${ }^{17}$ As a part of glutathione peroxidase, selenium (Se) acts, in performance with vitamin $\mathrm{E}$, to avoid free radical damage to cells. ${ }^{18}$ However, Se has a very narrow margin between the thresholds of functionality and toxicity; Se nanoparticles (SeNPs) have excellent bioavailability, high biological activity and low toxicity. ${ }^{19}$ Furthermore, SeNPs (5 to $200 \mathrm{~nm}$ ) were efficient for free radical scavenging both in vivo and in vitro. ${ }^{20} \mathrm{~A}$ benefit of using nano scale for medical technologies is that smaller devices are less invasive, faster and more sensitive than typical drug delivery. ${ }^{21}$ Moreover, SeNPs has a 7 -fold lower acute toxicity than sodium selenite in mice. ${ }^{22}$ In view of the previous concepts, this study was performed to investigate the modulatory effects of SeNPsGSE mixture in restoring the endogenous antioxidant defense capacity as well as glucose homeostasis in STZinduced diabetes in irradiated rats.

\section{MATERIALS AND METHODS}

\section{Chemicals and Drugs}

Allchemicalwas from Sigma-Aldrich (USA). Grape seed extract was obtained from (AL-Debeiky Pharma, Egypt). Glimepiride was purchased from (Sanofi Aventis, Egypt). Kits used in the experiment were purchased from (Biodiagnostic, Egypt). All other chemicals were of the highest commercially available grade.

\section{Animals}

Adult male albino rats, weighing 140-160 gm were purchased from the Animal House Colony of the Veterinary Serum and Vaccine Research Institute, Cairo, Egypt. Rats were housed under conventional laboratory conditions throughout the period of experimentation and fed standard rat pellet diet and allowed free access to water. The animal's treatment protocol has been approved by the Animal Care committee of the National Center for Radiation Research and Technology (NCRRT), Cairo, Egypt.

\section{Irradiation}

Whole body $\gamma$-irradiation of animals were performed using gamma cell 40 which is cesium- 137 irradiated unit 
belonging to National Center of Radiation and Technology (NCRRT) Cairo, Egypt. The dose rate was 0.996 $\mathrm{rad} / \mathrm{sec}$ at the time of exposure.

\section{Preparation and characterization of SeNPs-GSE Mixture}

SeNPs were formed by adding $0.04 \mathrm{mM}$ selenious acid and $0.2 \mathrm{mM}$ GSH solution(1:4 ratio v/v) containing bovine serum albumin to $100 \mathrm{ml}$ deionized water with stirring to initiate the reaction. The $\mathrm{pH}$ of the mixture was adjusted to 7.2. The reaction lasted 1 hour under sonication and Centrifuged at $20000 \mathrm{rpm}$ (Hettich cooling centrifuge; type Werk Nr. Made in Germany). Red elemental Se and oxidized glutathione (GSSG) were formed and characterized by measured average particle size and size distribution by Dynamic light scattering (DLS). The particle size and shape were observed by Transmission Electron Microscopy (TEM).

The pellets were mixed with the powders of Grape seed extract under sonication conditions for 1 hour to form mixture. ${ }^{20,23}$

\section{Induction anda ssessment of diabetes}

Overnight fasted animals were rendered diabetic by a single intraperitoneal (i.p) injection of STZ (45 mg/kg b.wt) in freshly prepared citrate buffer $(0.1 \mathrm{M}, \mathrm{pH} 4.5) \cdot{ }^{24} \mathrm{STZ}$ injected animals were given 5\% glucose solution for $48 \mathrm{~h}$ to prevent initial drug-induced hypoglycemic mortality as a result of enormous pancreatic insulin release. After one week of administration, blood glucose level was measured from tail vein using one touch select glucose meter (LifeScan Europe, Switzerland) rats exhibiting blood glucose levels $200 \mathrm{mg} / \mathrm{dl}$ or more were included in the study. ${ }^{25}$

\section{Treatment schedule}

Forty eight male albino rats were divided randomly into six groups, each contain eight animals. The dose of (SeNPs-GSE) mixture was chosen after preliminary experimental trials.

Group 1: Control group: Animals treated orally with saline for 14 days.

Group 2 :(Diabetic group): Rats were made diabetic by a single i.p injection of STZ (45 mg/kg b.wt).

Group 3: Irradiated group (Irr): Rats were received the same dose of saline as group (1) and on day14 rats were submitted to a single dose of whole-body $\gamma$-radiation (4 Gy).

Group 4: (Diabetic + Irr): Rats were received the same dose of STZ as group (2) and on day14 rats were submitted to a single dose of whole-body $\gamma$ - radiation (4 Gy).

Group 5: Rats were received the same dose of STZ as group (2) followed by oral administration of SeNPsGSE mixture (Se $6.7 \mu \mathrm{g} / \mathrm{kg}+$ GSE $110.7 \mathrm{mg} / \mathrm{kg}$ ) for 14 consecutive days then on day 14, rats were exposed to $\gamma$-radiation (4 Gy).

Group 6: Rats were made diabetic as in group 2 then injected orally with glimepiride $(1 \mathrm{mg} / \mathrm{kg})^{26}$ as a reference drug for 14 consecutive days, on day 14 rats were irradiated (4 Gy).

The animals were carefully monitored every day.

\section{Biochemical Studies}

At the end of the experimental period, animals were fasted overnight. Twenty-four hours after $\gamma$-irradiation, animals were anesthetized by (i.p) injection of urethane $\left(1.5 \mathrm{~g} / \mathrm{kg}\right.$ b.wt) ${ }^{27}$ Blood samples were withdrawn from the retro-orbital venous plexus using non heparinized

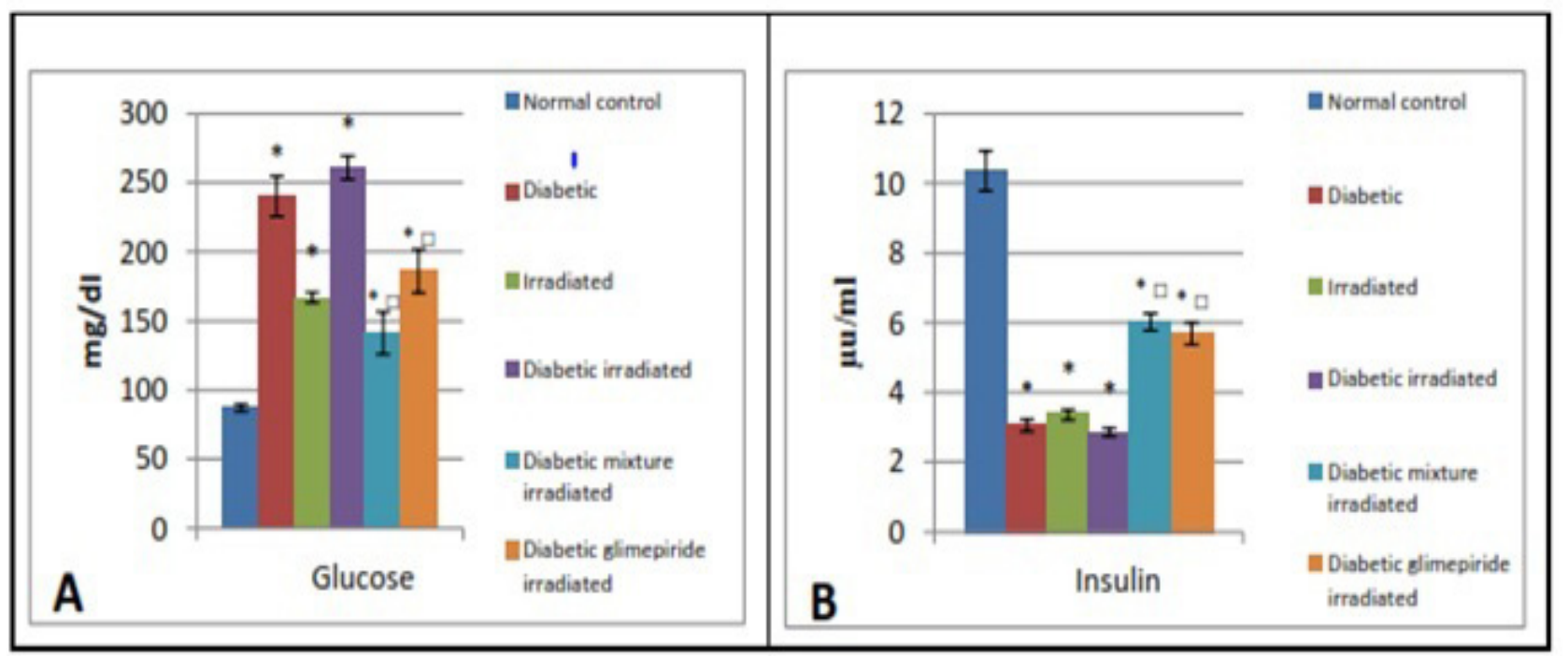

Figure 1: Effect of SeNPs - GSE mixture or glimepiride on glucose [A] \& insulin [B] levels in diabetic irradiated rats Rats were rendered hyperglycemic by a single i.p. injection of STZ (45 mg/kg). SeNPs-GSE mixture (Se $6.7 \mu \mathrm{g} / \mathrm{kg}+\mathrm{GSE} 110.7 \mathrm{mg} / \mathrm{kg})$ or glimepiride (1 mg/kg) were administered orally for 14 consecutive days then exposed to whole body $\gamma$-radiation ( 4 Gy). Results are expressed as means \pm SEM ( $n=8)$.* , "Significantly different from control group and diabetic irradiated group at $\mathrm{P}<0.05$. 
capillary tubes. Blood samples were centrifuged at 3000 rpm for 10 min using universal $16 \mathrm{R}$, Germany centrifuge. The clear sera were obtained for the determination of serum glucose, insulin and total antioxidant capacity levels. Liver was excised from the rats and homogenization was carried out using a homogenizer (Tri-R STIR$\mathrm{R}$ model K41). The homogenates were centrifuged at $4000 \mathrm{rpm}$ for $10 \mathrm{~min}$ at $4^{\circ} \mathrm{C}$ using centrifuge (Hettich, MIKRO 22, Germany) and was used to estimate MDA, SOD, CAT, GPx, Vit.C and Vit. E. Serum insulin level was estimated using immunoradiometric assay (IRMA) kit according to the method of Mullner. ${ }^{28}$ Serum glucose level was done using kit according to the method of Trinder. ${ }^{29}$ Serum TAC level was determined by the method of Koracevic ${ }^{30}$ using TAC kit, MDA content as an indication of Lipid peroxidation in livertissue was measured according to the method of Yoshioka and his colleagues ${ }^{31}$ GPx was assayed according to Gross, ${ }^{32-34}$ CAT enzyme activity was evaluated by the method of (Bergmeyer, ${ }^{33-35}$ SOD enzyme activity assayed by the method of Minami, ${ }^{34}$ Vit $\mathrm{C}$ content was estimated by the method of Roe and Kuether..$^{35}$ whereas, Vit. E content was evaluated by fluorometric method of Duve. ${ }^{36}$

\section{Statistical Analysis}

Data are expressed as means \pm SEM of eight animals. Statistical significance was taken as $\mathrm{P}<0.05$ for all experiments, using one way analysis of variance (ANOVA) followed by Tukey-Kramer test multiple comparisonsusing Graph pad software prism (version 3).

\section{RESULTS}

\section{Biochemical evaluations}

\section{Serumglucose and Insulin Levels}

Whole body exposure of rats to a single dose of $\gamma$-radiation (4 Gy)or induction of diabetes by STZ $(45 \mathrm{mg} / \mathrm{kg}$ i.p) showed a significant increase in serum glucose level by $91.4 \%$ and $175,52 \%$ respectively as compared to nor-

\begin{tabular}{|c|c|c|}
\hline $\begin{array}{c}\text { Table 1: Effect of SeNPs-GSE mixture orglimepiride on TAC and MDAlev- } \\
\text { els in diabeticirradiated rats }\end{array}$ \\
\hline Group & SerumTAC (mM/L) & Liver MDA (nmol/g tissue) \\
\hline Parameter & $1.145 \pm 0.01$ & $80.17 \pm 3.4$ \\
\hline Normal control & $0.77 \pm 0.03^{\circ}$ & $198.3 \pm 3.6^{*}$ \\
\hline Diabetic & $0.768 \pm 0.01^{\circ}$ & $135.2 \pm 3.1^{\circ}$ \\
\hline Irr & $0.768 \pm 0.01^{\circ}$ & $292.2 \pm 1.6^{*}$ \\
\hline Diabetic+irr & $0.908 \pm 0.007^{\circ}$ & $119.2 \pm 3^{*}$ \\
\hline Diabetic+ SeNPs-GSE+Irr & $1.057 \pm 0.02^{\circ}$ & $119.5 \pm 3.2^{*}$ \\
\hline Diabetic+ glimepiride+Irr &
\end{tabular}

Rats wererendered hyperglycemicbyasinglei.p. injection of (STZ; 45 mg/kg); SeNPs-GSE mixture (Se6.7 $\mu \mathrm{g} / \mathrm{kg}$ +GSE $110.7 \mathrm{mg} / \mathrm{kg}$ ) orglimepiride $(1 \mathrm{mg} / \mathrm{kg}$ ) were administered orally for 14 consecutive days then exposedto whole body gamma radiation ( $4 \mathrm{~Gy}$ ). Results are expressed as means $\pm \operatorname{SEM}(n=8) .{ }^{*}$, ${ }^{\square}$ Significantlydifferent fromcontrolgroupanddiabetic irradiatedgroup at $\mathrm{P}<0.05$.

\section{Table 2: Effect of SeNPs- GSE mixture orglimepiride on some liver anti- oxidant enzymes activity in diabetic irradiated rats}

\begin{tabular}{|c|c|c|c|}
\hline Parameter & $\begin{array}{c}\text { CAT } \\
\text { (U/g tissue) }\end{array}$ & $\begin{array}{c}\text { SOD } \\
(\boldsymbol{\mu g} / \mathbf{g} \text { tissue) }\end{array}$ & $\begin{array}{c}\text { GPx } \\
(\mathbf{n m o l} / \mathbf{m i n} / \mathbf{g} \text { tissue) }\end{array}$ \\
\hline Normalcontrol & $57.26 \pm 1.2$ & $78.8 \pm 1.4$ & $2.84 \pm 0.05$ \\
\hline Diabetic & $22.5 \pm .53^{*}$ & $63.2 \pm 0.9^{*}$ & $1.64 \pm 0.12^{*}$ \\
\hline Irr & $20.17 \pm 1.2^{*}$ & $61.7 \pm 0.5^{*}$ & $1.72 \pm 0.04^{*}$ \\
\hline Diabetic+ lirr & $19.07 \pm 0.9^{*}$ & $54.5 \pm 1.3^{*}$ & $1.34 \pm 0.09^{*}$ \\
\hline Diabetic+ SeNPs-GSE+Irr & $29.8 \pm 2.1^{*}$ & $61 \pm 0.4^{*}$ & $2.056 \pm 0.07^{*}$ \\
\hline Diabetic + Glime piride+Irr & $31.68 \pm 1.6^{*}$ & $60.6 \pm 0.9^{*}$ & $2.61 \pm 0.14^{\circ}$ \\
\hline
\end{tabular}

Rats were rendered hyper glycemicbyasinglei.p. injection of (STZ; $45 \mathrm{mg} / \mathrm{kg}$ ); SeNPs-GSE mixture (Se6.7 $\mu \mathrm{g} /$ $\mathrm{kg}+\mathrm{GSE} 110.7 \mathrm{mg} / \mathrm{kg}$ ) orglimepiride $(1 \mathrm{mg} / \mathrm{kg}$ ) were administered orally for 14 consecutivedays then exposedto whole body gamma radiation ( 4 Gy). Results are expressed as means \pm SEM $(n=8)$.*, "Significantly different from control group and diabetic irradiated group at $\mathrm{P}<0.05$. 


\begin{tabular}{|c|c|c|}
\hline $\begin{array}{c}\text { Table 3: Effect of SeNPs -GSE mixture orglimepirideon Vitamin C\&E } \\
\text { content in diabetic irradiated Rats }\end{array}$ & $\begin{array}{c}\text { Vitamin C (Liver) } \\
(\mu \mathrm{g} / \mathrm{mg} \text { tissue) }\end{array}$ & $\begin{array}{c}\text { Vitamin E (Liver) } \\
(\boldsymbol{\mu} / \mathrm{mg} \text { tissue) }\end{array}$ \\
\hline Garameter & $2.26 \pm 0.06$ & $0.414 \pm 0.007$ \\
\hline Normal control & $1.11 \pm 0.04^{*}$ & $0.123 \pm 0.004^{*}$ \\
\hline Diabetic & $1.07 \pm 0.04^{*}$ & $0.188 \pm 0.01^{*}$ \\
\hline Irr & $1.009 \pm 0.04^{*}$ & $0.139 \pm 0.01^{*}$ \\
\hline Diabetic+ Irr & $1.616 \pm 0.07^{*}$ & $0.275 \pm 0.003^{*}$ \\
\hline Diabetic+ SeNPs-GSE + Irr & $1.783 \pm 0.04^{*}$ & $0.235 \pm 0.008^{*}$ \\
\hline Diabetic+ glimepiride+ Irr &
\end{tabular}

Rats wererendered hyperglycemicbyasinglei.p. injection of (STZ; $45 \mathrm{mg} / \mathrm{kg})$; SeNPs-GSE mixture (Se6.7 $\mu \mathrm{g} / \mathrm{kg}+$ GSE $110.7 \mathrm{mg} / \mathrm{kg}$ ) orglimepiride $(1 \mathrm{mg} / \mathrm{kg}$ ) were administered orally for 14 consecutive days then exposed to whole body gamma radiation ( $4 \mathrm{~Gy}$ ). Results are expressed as means $\pm \mathrm{SEM}$ $(n=8)$ * , 口ignificantly different from control group and diabetic irradiated group at $P<0.05$.

mal group Figure 1(A). This elevation in glucose level was accompanied by a significant decrease in serum insulin level by $67.5 \%$ in irradiated group and $70.5 \%$ in diabetic group as compared to normal control group (Figure 1B). The combined STZ treatment and $\gamma$-radiation exposure intensified the damaging effect induced by either STZ or irradiation alone, as it recorded $199.2 \%$ for serum glucose and $72.46 \%$ for serum insulin comparing to control values (Figure 1 A, B). Administration of SeNPs-GSE mixture or glimepiride after induction of diabetes exerts significant amelioration on the tested parameters(Figure 1 A, B).

\section{Serum TAC and Liver tissue MDA Levels}

As shown in Table 1 serum TAC significantly decreased in diabetic, irradiated and diabetic- irradiated groups by $32.4 \%, 32.6 \%$ and $32.6 \%$ respectively as compared to normal control group. This decrease in TAC was accompanied by increase in liver MDA level by $147.3 \%, 68.6 \%$ and $264.47 \%$. Administration of SeNPs-GSE mixture or glimepiride before $\gamma$-irradiation exerts significant enhancement on serum TAC with reduction on liver MDA level.

\section{Liver Enzyme antioxidants activities}

The result of the present study, have demonstrated that rats treated with STZ or exposed to irradiation (4 Gy) or double treatment of STZ and Irradiation showed a significant decrease in liver enzyme activities of CAT $(60.7 \%, 64.7 \%, 66.7 \%)$, SOD $(19.8 \%, 21.7 \%$ and $30.8 \%)$ and GPx (42.2\%, 39.4\% and 52.8\%) respectively as compared to normal values (Table 2). Diabetic rats treated with SeNPs-GSE mixture or glimepiride before $\gamma$-irradiation exert significant improvement on these enzymatic antioxidants as compared to diabetic irradiated group (Table 2).

\section{Liver Tissue content of VitC and VitE}

Data in Table 3 shows that exposing animals to STZ alone or $\gamma$-radiation (4 Gy) as a single dose caused a significant decrease in both liver tissue vit.C and Vit.E contents. The percentage of these decreases recorded by $50.8 \%$ and $70 \%$ for STZ and $52.6 \%$ and $56.1 \%$ for $\gamma$-radiation respectively as compared to the normal control group. Whole body exposure of rats to $\gamma$-radiation (4Gy) following STZ injection showed a significant decline in the levels of liver Vit C andVit E by 55.35\% and 66.09\% respectively,as compared to control group. Treatment by SeNPs-GSE mixture or glimepiride after induction of diabetes restore liver Vit. C and Vit. E levels.

\section{Characterization of SeNPs}

Application of DLS technique revealed that the SeNPs size were distributed in nano scale and the main particle diameter was $81.4 \mathrm{~nm} \pm 8.7$ (SD). TEM examination of the solution containing Se nanoparticles demonstrated particles within nano range and main particle diameter of $73.1 \mathrm{~nm}$.

\section{DISCUSSION}

STZ is a toxin that selectively destroys the beta cells of islets of Langerhans irreversibly, causing reduction of insulin secretion and increase in blood glucose level. ${ }^{37}$ This is in accordance with our study, rats injected with STZ exerted significant increase in serum glucose concentration with a decrease in serum insulin level. STZ resulted as well, in a marked decrease in liver enzyme activities of SOD, CAT, GPx, and serum TAC levels. These decreases in the oxidative stress parameters were accompanied by an elevation in liver lipid peroxidation level. Previous investigators ${ }^{38}$ accounted comparable data. They noted a decrease in the antioxidant enzyme activities. They stated that the augmentation in the oxidative stress could be attributed to the depletion of GSH during diabetes, ${ }^{39}$ as well as, the reduced activity of GPx resulting from radical induced inactivation and 
glycation of the enzyme in addition to excess ROS that is responsible for glucose and lipid auto oxidation. ${ }^{38}$ Vit $\mathrm{C}$ and $\mathrm{E}$ are endogenous non enzymatic antioxidants, they detoxify free radicals directly. Vit C particularly sequester the singlet oxygen radical, alleviate the hydroxyl radical while Vit $\mathrm{E}$ transfers its phenolic hydrogen to a peroxyl free radical of peroxidized polyunsaturated fatty acids, thereby breaking the radical chain reaction and preventing the peroxidation of membrane lipids. ${ }^{40}$ In diabetic rats there were significant decreases in the levels of liver tissue Vit $\mathrm{C}$ and Vit E contents. The decreased level of VitC may be due to either increased utilization as an antioxidant defense against increased ROS or to a decrease in glutathione level, since glutathione is required for the recycling of ascorbic acid. ${ }^{41}$

Ionizing radiation is known to induce oxidative stress through generation of ROS which is an imbalance in prooxidant, antioxidant status in the cell. ${ }^{42}$ In the present study, $\gamma$-irradiation caused a noticeable increase in serum level of glucose concentration with a decrease in serum insulin level. These data agree with that reported in previous study of $\mathrm{Kafafy}^{43}$ who reported a significant increase in blood glucose concentration after exposure to whole body $\gamma$-irradiation and this might be related to endocrine abnormalities induced by irradiation that promote the secretion of biologically active peptide which has relation with carbohydrate metabolism by increasing gluconeogenesis in liver . SOD, CAT and GPx constitute the major enzymatic antioxidant defenses which convert active oxygen molecules into nontoxic compounds. Our results revealed that exposure to $\gamma$-radiation decreased the activities of these antioxidant enzymes in the liver tissues, indicating oxidative stress in the liver. The obtained results were in agreement with Kalpana ${ }^{44}$ who reported that exposure to $4 \mathrm{~Gy} \gamma$-radiations decreased the activities of these antioxidant enzymes in the liver.

Lipid peroxidation refers to the oxidative stress degradation of lipid in which malondialdehyde (MDA) is one of its end products. ${ }^{45}$ It mostly affects polyunsaturated fatty acids causing tissue damage. ${ }^{46}$ Our results observed an elevation in MDA levels in liver of irradiated rats which may be due to the free radicals attack on cell membrane phospholipids and circulating lipids. ${ }^{47}$ Furthermore, in the present study there were significant decreases in Vit. $\mathrm{C}$ and Vit. E levels in irradiated group which may be due to increased ROS by irradiation. Result of the current study showed that double treatment of STZ induced diabetes in rats and $\gamma$-irradiation resulted in marked alterations in all the tested parameters which were more pronounced than that observed in each model alone.
Our result further indicated that diabetic rats orally treated with SeNPs-GSE mixture before $\gamma$-irradiation significantly ameliorated the double treatment effect of STZ and gamma irradiation .Consequently, it increases the levels of liver enzymes activities of SOD, CAT, GPx as well as Vit. C, Vit. E contents. Such treatment caused augmentation in serum insulin, serum TAC levels accompanied by a decrease in the level of serum glucose and liver MDA.

Literature survey revealed that GSE exhibit insulinomimetic properties ${ }^{48}$ and anti-hyperglycemic effects ${ }^{49}$ in addition to its antioxidant activity..$^{50}$

These effects may be due to antidiabetic activity of the natural plant phenolic compounds. ${ }^{51}$ The antioxidant activity of GSE may be due to the inhibition of the oxidation of plasma lipids. Moreover, it is able to scavenge hydroxyl radicals, peroxyl radicals, superoxide anion radicals. ${ }^{52}$

On the other hand, previous studies showed that selenium plays important roles in the enhancement of the antioxidant defense system, ${ }^{53}$ protective function against ionizing radiation ${ }^{54}$ and decrease blood glucose level. ${ }^{55}$ Se acts by scavenging the freeradicals and ROS. ${ }^{56}$ This indicates that Se moderates oxidative stress-mediated complication. Moreover; Nanoparticles are designed to carry drugs and bring that medication all the way to the diseased cells in a body without harming the healthy cells. Nano-Se possesses equal efficacy of selenium with much lowertoxicity. ${ }^{57}$ Therefore, in the present study the tested combination of both SeNPs and GSE may reflect the sum of efficiency of either compound alone. Thus, acting with more than one mechanism of action including, reduction of ROS and scavenging of free radicals as well as an improvement of the tissue enzymatic and non-enzymatic antioxidant activities.

In the present study, glimepiride significantly elevated serum insulin and significantly decrease serum glucose levels in STZ-diabetic rats. This result is in agreement with other authors ${ }^{58}$ Furthermore, it lowered serum TBARS level. Hence, restoring the endogenous antioxidant defense capacity; our results were in accordance with the work of Kakadiya and Shah. ${ }^{59}$ The present data suggest that glimepiride may possess antioxidant activity against oxidative stress. This postulation runs in parallel with other work. ${ }^{60}$ This antioxidant effect of glimepiride may be attributed to its activation of antioxidant enzymes such as SOD. ${ }^{61}$ In spite of glimepiride is an important oral hypoglycemic agent of the sulfonylurea group itexerts severe side effects such as gastrointestinal disorders, hypersensitivity reactions ${ }^{62}$ and severe hypoglycemia which may be life-threatening. ${ }^{63}$ Therefore; there is a need to look for natural, newer and alternative therapy for DM to be more effective and less toxic. 
In the present study there were no significant differences between glimepiride and SeNPs-GSE mixture in all the tested parameters. As a result, it may be fulfilled that SeNPs-GSE mixture possess antioxidant and antidiabetic activity. The tested combination (SeNPs-GSE) mixture is more or less equally active as that of the standard tested ant-diabetic drug glimepiride.

\section{CONCLUSION}

SeNPs-GSE mixture should be considered as an excellent subject for potential studies as natural anti-diabetic as well as radio protector comparable to synthetic hypoglycemic drug. The obtained data appreciate the usage of such combination for treating diabetic patients undergoing radiotherapy.

\section{ACKNOWLEDGEMENT}

The authors are appreciated to the staff member of gamma irradiation unit for their cooperation in carrying out the irradiation experiment.

\section{CONFLICT OF INTEREST}

The authors declared that there is no conflict of interest.

\section{ABBREVIATION}

$\begin{array}{ll}\text { Se } & : \text { Selenium } \\ \text { SeNPs } & : \text { Se nanoparticles } \\ \text { GSE } & : \text { grape seed extract } \\ \text { SeNPs-GSE } & : \text { selenium nanoparticles-grape seed } \\ & \text { extract } \\ \text { STZ } & : \text { streptozotocin } \\ \text { Irr } & : \text { Irradiated } \\ \text { ROS } & : \text { reactive oxygen speices } \\ \text { MDA } & : \text { malondaldhyde } \\ \text { TAC } & : \text { total antioxidant capacity } \\ \text { CAT } & : \text { catalase } \\ \text { GPx } & : \text { glutathione peroxidase } \\ \text { SOD } & : \text { superoxide dismutase } \\ \text { Vit.C } & : \text { vitamin C } \\ \text { Vit.E } & : \text { vitamin E } \\ \text { NCRRT } & : \text { National Center for Radiation } \\ & \text { Research and Technology. }\end{array}$

\section{SUMMARY}

- Gamma irradiation intensify the toxic effect of STZ induce diabetes.

- SeNPs-GSE mixture showed protection against gamma irradiation.

- SeNPs-GSE mixture possesses anti diabetic activity.

- The tested combination (SeNPs-GSE) mixture is more or less equally active as that of the reference antidiabetic drug glimepiride.

\section{About Authors}

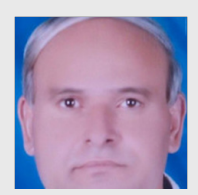

Prof Dr Ahmed Ibrahim: Elbatal Professor of Microbial Biotechnology and Nanotechnologyat the National centre of radiation research and technology, Cairo Egypt. He graduated from faculty of Science Ain Shams university 1979.

Prof Dr Seham Hassan Mohamed Hassan: Professor of pharmacology and toxicologyat the National centre of radiation research and technology, Cairo Egypt. Pre-head of drug department of radiation research. She graduated from of faculty of pharmacy Cairouniversity 1973.

Prof Dr Mervat El-SayedAskar: Professor of Biobchemistry and head of biochemitry department at faculty of pharmacy Zagazig University Egypt. graduated from Zagazig university 1980.

Dr HananFahmyabdelhameed: Lecturer of biochemistry at the national centre of radiation research and technology (Drug department of radiation research). Graduated from faculty of pharmacy Cairo university. Her doctoral research focused on protective effect of taurine and beta blocker on myocardial infarction induced in irradiated rats.

Rasha Mohamed Ahmed Abdelaleem: Pharmasist in the National Centre of Radiation Research and Technology.

\section{REFERENCES}

1. Ostrau C, Hülsenbeck J, Herzog M, Schad A, Torzewski M, Lackner KJ. Lovastatin attenuates ionizing radiation-induced normal tissue damage in vivo. Radiother Oncol. 2009; 92(3): 492-9.
2. Boerma M, Hauer-Jensen M. Preclinical research into basic mechanisms of radiation- induced heart disease. Cardiol Res Pract. 2011; 211(20): 1-8.

3. Giacco F, Brownlee M. Oxidative stress and diabetic complications. Circ Res. 2010; 107(9): 1058-70. 
4. Davis SN. The role of glimepiride in the effective management of Type 2 diabetes. J Diabetes Complicat. 2004; 18(6): 367-76.

5. Stone HB, Moulder JE, Coleman CN, Ang KK, Anscher MS, Barcellos$\mathrm{Hoff} \mathrm{MH}$, et al. Models for evaluating agents intended for the prophylaxis, mitigation and treatment of radiation injuries. Report of an $\mathrm{NCl}$ Workshop. Radiat Res. 2004; 162(6): 711-28.

6. Rades D, Fehlauer F, Bajrovic A, Mahlmann B, Richter E, Alberti W. Serious adverse effects of amifostine during radiotherapy in head and neck cancer patients. Radiother Oncol. 2004; 70(3): 261-4.

7. Weiss JF, Landauer MR. Protection against ionizing radiation by antioxidant nutrients and phytochemicals. Toxicology 2003; 189(1): 1-20.

8. Jagetia GC. Radioprotective potential of plants and herbs against the effect of ionizing radiation. J Clin Biochem Nutr. 2007; 40(2): 74-81.

9. Kijima I, Phung S, Hur G, Kwok SL, Chen S. Grape seed extract is an aromatase inhibitor and a suppressor of aromatase expression. Cancer Res. 2006; 66(11): 5960-7.

10. Preuss HG, Bagchi D, Bagchi M. Protective effects of a novel niacin-bound chromium complex and a grape seed proanthocyanidin extract on advancing age and various aspects of syndrome X. Ann NY Acad Sci. 2002; 957(1): 250-9.

11. Mahmoud YI. Grape seed extract neutralizes the effects of Cerastes cerastes cerastes post-synaptic neurotoxin in mouse diaphragm. Micron 2013; 44: 298-2.

12. Albrecht MA, Evans CW, Raston CL. Green chemistry and the health implications of nanoparticles. Green Chem. 2006; 8(5): 417-32.

13. Susa M, lyer AK, Ryu K, Hornicek FJ, Mankin H, Amiji MM, et al. Doxorubicin loaded polymeric nanoparticulate delivery system to overcome drug resistance in osteosarcoma. BMC. Cancer 2009; 9(1): 399.

14. Surendiran A, Sandhiya S, Pradhan SC, Adithan C. Novel applications of nanotechnology in medicine. Indian J Med Res. 2009; 130(6): 689-01.

15. Baker D, Campbell RK. Vitamin and mineral supplementation in patients with diabetes mellitus. Diabetes Educ. 1992; 18(5): 420-7.

16. Papp LV, Lu J, Holmgren A, Khanna KK. From selenium to seleno proteins: synthesis, identity, and their role in human health. Antioxid Redox Signal. 2007; 9(7): 775-806.

17. Erbayraktar Z, Yilmaz O, Artmann AT, Cehreli R, Coker C. Effects of selenium supplementation on antioxidant defense and glucose homeostasis in experimental diabetes mellitus. Biol Trace Elem Res. 2007; 118(3): 217-26.

18. Hawkes WC, Wilhelmsen EC, Tappel AL. Abundance and tissue distribution of selenocystine-containing proteins in the rat. J Inorg Biochem. 1985; 23(2): 77-92.

19. Tanaka T, Kohno H, Murakami M, Kagami S, El-Bayoumy K. Suppressing effects of dietary supplementation of the organoselenium 1,4-phenylenebis(methylene) selenocyanate and the Citrus antioxidant auraptene on lung metastasis of melanoma cells in mice. Cancer Res. 2000; 60(15): 3713-16.

20. Huang $B$, Zhang J, Hou J, Chen C. Free radical scavenging efficiency of Nano-Se in vitro. Free Radic Biol Med. 2003; 35(7): 805-13

21. Boisseau $P$, Loubaton $B$. Nano-medicine, nanotechnology in medicine. CR Phys. 2011; 12(7): 6-20.

22. Shi J, Votruba AR, Farokhzad OC, Langer R. Nanotechnology in drug delivery and tissue engineering: from discovery to applications. Nano Lett. 2010; 10(9): 3223-30.

23. El-Batal Al, Thabet NM, Moustafa AO, Abdel Ghaffar ARB, Azab KS. Amelioration of oxidative damage induced in gamma irradiated rats by nano selenium and lovastatin mixture. World Appl Sci J. 2012; 19(7): 962-71.

24. Kanchana G, Malini $P$, Rajadurai $M$. Anti-diabetic efficacy of ellagic acid in streptozotocin induced diabetes mellitus in albino wister rats. Asian J Pharm Clin Res. 2011; 4(3): 124-8.

25. Weng Y, Yu L, Cui J, Yan-Rong Z, Chao G, Guo W, et al. Antihyperglycemic, hypolipidemic and antioxidant activities of total saponins extracted from Aralia taibaiensis in experimental type 2 diabetic rats. J Ethno Pharmacol. 2014; 152(3): 553-60.

26. Gayasuddin MD, Kavimani S, Shakil SS, Venkataiah1 G, Parvez Md. Effect of Ananascomosus L. juice on the efficacy of glimepiride in alloxan induced diabetic rats. Der Pharmacia Lett. 2013; 5(1): 323-6.

27. Lei-Ming R, Yong-Jie Z, Zhang-Sen H, Hong-Mei H, Hai-Gang L, Ding Z. Berberine improves neurogenic contractile response of bladder detrusor muscle in streptozotocin-induced diabetic. J Ethno Pharmacol. 2013; 150(3): 1128-36.

28. Müllner S, Neubauer H, König W. A radio immunoassay for the determination of insulins from several animal species, insulin derivatives and insulin precursors in both their native and denatured state. J Immunol Meth. 1991; 140(2): 211-8.
29. Trinder P. Determination of glucose in blood using glucose oxidase with an alternative oxygen acceptor. Ann Clin Biochem. 1969; 6: 24-7.

30. Koracevic D, Koracevic GJ. Method for the measurement of antioxidant activity in human fluids. Clin Pathol. 2001; 54(5): 356-61.

31. Yoshioka T, Kawada K, Shimada T, Movi M. Lipid per oxidation in maternal and cord blood and protective mechanism against activated oxygen toxicity in the blood. Am J Obstet Gynec. 1979; 135(3): 372-6.

32. Gross RT, Bracci R, Rudolph N, Schroeder E, Kochen JA. Hydrogen peroxide toxicity and detoxification in the erthyrocytes of new born infants. J. Blood 1967; 29(4): 481-93

33. Bergmeyer HU. Methods of enzymatic analysis. $3^{\text {rd }}$ ed Verlagchemie, Weinheim, Germany; 1983. 273-86.

34. Minami M, Yoshikawa H. A simplified assay method of superoxide dismutase activity for clinical use. Clin Chim Acta. 1979; 92(3): 337-42.

35. Roe $\mathrm{JH}$, Kuether CA. The determination of ascorbic acid in whole blood and urine through the 2-4-dinitrophenyl hydrazine derivative of dihydroascorbic acid. J Biol Chem. 1943; 147(1): 399-400.

36. Duve DC, Pressman BC, Gianetto R, Wattiaux R, Appelmans F. Tissue fractionation studies. 6 . Intracellular distribution patterns of enzymes in ratliver tissue. Biochem J. 1955; 60(4): 604-17.

37. Vismaya Rajini PS. Exacerbation of intestinal brush border enzyme activities and oxidative stress in streptozotocin-induced diabetic rats by monocrotophos. Chem Biol Interact. 2014; 211(25): 11-9.

38. Seung Ju, Yang SJ, Lee WJ, Kim EA, Nam KD, Hahn HG. Effects of $\mathrm{N}$-adamantyl-4-methylthiazol-2-amine on hyperglycemia, hyperlipidemia and oxidative stress in streptozotocin-induced diabetic rats. Eur $\mathrm{J}$ Pharmacol. 2014; 736(5): 26-34

39. Coskun ZM, Sacanc O, Karatugd A, Turka N, Yanardagc R, Bolkentd S, et al. Regulation of oxidative stress and somatostatin, cholecystokinin, a pelin gene expression by ghrelin in stomach of newborn diabetic rats. Acta Histo chem. 2013; 115(7): 740-7.

40. Opara EC. Oxidative stress, micronutrients, diabetes mellitus and its complications. JR Soc Promot. Health 2002; 122(1): 28-34.

41. Jin XL, Shao Y, Wang MJ, Chen LJ, Jin GZ. Tetrahy droprotoberberines inhibit lipid peroxidation and scavenge hydroxyl free radicals. Acta Pharmacol Sin. 2000; 21(5): 477-80.

42. Bhosle SM, Huilgol NG, Mishra KP. Enhancement of radiation-induced oxidative stress and cytotoxicity in tumor cells by ellagic acid. Clin Chim Acta. 2005; 359(1): 89-100

43. Kafafy YA, Roushdy H, Abdel-Haliem M, Mossad M, Ashry O, Salam S. Protective role of green tea administration against radiation-induced changes in pregnant rats. Egypt J Rad Sci Appli. 2005; 18(2): 367-84.

44. Kalpana KB, Devipriya N, Srinivasan M, Vishwanathan P, Thayalan K, Menon VP. Evaluating the radio protective effect of hesperidin in the liver of Swiss albino mice. Eur J Pharmacol. 2011; 658(2): 206-12.

45. Asha VV. Preliminary studies on hepatoprotective activities of Momordicas abangulata and Naragam aalat. Indian J Pharmacol. 2001; 33(4): 276-9.

46. Khan RA, Khan MR, Sahreen S, Ahmed M. Evaluation of phenolic contents and antioxidant activity of various solvent extracts of Sonchus asper (L.) Hill. Chem Cent J. 2012; 6(1): 6-12.

47. Smina TP, Maurya DK, Devasagayam TPA, Janardhanan KK. Protection of radiation induced DNA and membrane damages by total triterpenes isolated from Ganoderma lucidum (Fr.) P. Karst. Chem Boil Interact. 2015; 233(55): 1-7.

48. Adisakwattana S, Jiphimai P, Prutanopajai P, Chanathong B, Sapwarobol S, Ariyapitipan T. Evaluation of a-glucosidase, a-amylase and protein glycation inhibitory activities of edible plants. Int J Food Nutr. 2010; 61(3): 295-305.

49. Suwannaphet W, Meeprom A, Yibchok-Anun S, Adisakwattana S. Preventive effect of grape seed extract against high-fructose diet-induced insulin resistance and oxidative stress in rats. Food Chem Toxicol. 2010; 48(7):1853-7.

50. Chedea VS, Braicu C, Socaciu C. Antioxidant/prooxidant activity of a polyphenolic grape seed extract. Food Chem. 2010; 121(11): 132-9.

51. You Q, Chen F, Wang X, Jiang Y, Lin S. Anti-diabetic activities of phenolic compounds in muscadine against alpha-glaucosidase and pancreatic lipase. LWT-Food Sci Technol. 2012; 46(1): 164-8.

52. Yilmaz $\mathrm{Y}$, Toledo RT. Major flavonoids in grape seeds and skins: antioxidant capacity of catechin, epicatechin, and gallic acid. J Agric Food Chem. 2004; 52(2): 255-60. 
53. Hasanuzzaman M, Fujita M. Selenium pretreatment up regulates the antioxidant defense and methylglyoxal detoxification system and confers enhanced tolerance to drought stress in rapeseed seedlings. Biol Trace Elem Res. 2011; 14(3): 1758-6.

54. Imamura S, Yabu T, Ishihara K, Yamashita Y, Yamashita M. Ionizing radiation resistance mediated by the novel selenium-containing antioxidant selenoneine. The FASEB. 2013; 27(1): 757-63.

55. Satyanarayana S, Sekhar JR, Kumar KE, Shannika LB, Rajanna B, Rajanna S. Influence of selenium (antioxidant) ongliclazide induced hypoglycaemia/ antihyperglycaemia in normal/alloxan-induceddiabetic rats. Mol Cell Biochem. 2006; 283(1-2): 123-7.

56. Al-Othman AM, Al-Numair S, El-Desoky KG, Yusuf K, Al Othman ZA, AboulSoud MA, et al. Protection of a -tocopherol and selenium against acute effects of Malathion on liver and kidney of rats. AJPP. 2011; 5(10): 1263-71.

57. Zhang J, Wang X, Xu T. Elemental Selenium at Nano Size (Nano-Se) as a Potential Chemo preventive Agent with Reduced Risk of Selenium Toxicity: Comparison with Se-Methylselenocysteine in Mice. Toxicol Sci. 2008; 101(1): 22-31.
58. Hsu YJ, Lee TH, Chang CLT, Huang YT, Yang WC. Anti-hyperglycemic effects and mechanism of Bidens pilosa water extract. J Ethno Pharmacol. 2009; 122(2): 379-83.

59. Kakadiya J, Shah N. Comparison effect of Pioglitazone and Glimepiride alone on renal function marker in experimentally induced renal damage in diabetic rats. J Appl Pharmaceutical Sci. 2011; 1(03): 72-6.

60. Rabbani SI, Devi K, Khanam S. Inhibitoy effect of glimepride on nictinamidestreptozotocin induced nuclear damage and sperm abnormality in diabetic wistar rats. Indian J Exp Biol. 2009; 47(10): 804-10.

61. Valko M, Leibfritz D, Moncol J, Cronin Mazur M, Telser J. Free radicals and antioxidants in normal physiological functions and human disease. Int $\mathrm{J}$ Bio chem Cell boil. 2007; 39(1): 44-84.

62. Paice B, Paterson K, Lawson D. Undesired effects of the sulphonylurea drugs: Adverse drug reactions and acute poisoning reviews adverse drug react. Acute Poisoning Rev. 1985; 4(1): 23-36.

63. Szoke E, Gosmanov NR, Sinkin JC, Nihalani A, Fender AB, Cryer PE, et al. Effects of glimepiride and glyburide on glucose counter regulation and recovery from hypoglycemia. Metabolism 2006; 55(1): 78-83. 